\title{
A Study of selected poems from Sahitya Akademi Award- Winning Poetry Collection Idu Ningthou by Memchoubi
}

\author{
Dr. Anuradha Nongmaithem* \\ Assistant Professor of English, Department of Management, Humanities and Social Sciences, National Institute \\ of Technology Agartala, Jirania, Brajala, West Tripura- 799046, India
}

\begin{abstract}
*Corresponding Authors: Dr. Anuradha Nongmaithem, Assistant Professor of English, Department of Management, Humanities and Social Sciences, National Institute of Technology Agartala, Jirania, Brajala, West Tripura- 799046, India
\end{abstract}

\begin{abstract}
The paper is a study of Sahitya Akademi award-winning poetry collection for 2008 called IduNingthou by Memchoubi which is translated by Kh. Kunjo Singh. The present study is taken from the translated version of the poems, there are total 54 poems and 12 poems are taken up for study. The researchers have randomly chosen few poems to study the representation of gender, class and society of Manipur from the poets' perspective. The paper will highlight the societal norms of Manipuri tradition and the limitation of the women roles in Manipuri society. The pitch of the study is the sketches of ideal Manipurthrough the lens of the poet's vision. The poet drew her inspiration of the nature and tries conveying her deepest most thought through her lines. The study is more of analytical attempting to study between the lines. The poet's view about women in general, her agitation towards the societal tradition and her vision of better Manipur and a strong sense of identity is attempted to study in this paper.
\end{abstract}

Keywords: Memchoubi, Feminism, Meitei, Atrocities, Class

\section{INTRODUCTION}

Ch. Manihar Sigh's in his book, A History of Manipuri Literature, said that the Pre-World War II waspredominantly occupied by Chaoba, Kamal and Anghal for the poetry genre. Women writing in Manipuri literature were laid by M.K. Binodini, Thoibi and Kh. Pramodini. In an article by E.NilakantaSinghentitled "Promise of Creativity" it is said the "Poetry is something which the Manipuri's adore, in many forms such as epics, ballads and lyrics" (155).In a book Woman Activism: In Contemporary Manipuri Literature by Dr S. Shantibala and Dr. W. KumariChanu in the third chapter of the book "Profiles of Woman Activists In Poetry", the chapter elaborately trace the journey of women contribution in poetry. KhwairakpamAnandini (1952- ) became the first Manipuri womanpoet with her publication of her collected poems called SajibugiLeirangin 1967. Women poetsmarked the entry after the publication of SajibugiLeirang, carving a permanent place in the course ofmodern Manipuri poetry. Most of the women poets focus their writings more on religious and nature,but in the later stage women poet focuses more in expressing their feminine consciousness and identity. These thought was seen in the works of M. Borkeina, Arambam Ongbi Memchoubitonamea few. In the early stages of the poetry written by women the main thrust was on nature and not much on the problems of women, but in the later stages women gradually focuses more on issues identitiesandrole of women in society, women started getting more conscious about empowerment and responsibilities. ArambamOngbiMemchoubi (1955- )is one of the outspoken poet, writer and activist of Manipur. She is one of the leading poets who are vocal and actively involved in bringingabout changes in the status of women in Manipur. She has been associating with the MachaLeimaanorganization who specially promotes free education for poor girl children, and many more socialactivities to help the down trodden people of Manipur. She has written series of poetry collectionsNonggoubi,1984isher first collection of poetry, AndrogiMei1990 is the second collection, SandrembiChaisra, 1993 is her third collection, EigiPalemNungsibi1998 is the fourth collection, IduNingthou, 2005 is the fifth collection, Leisang, 2008 and July 15 to name a few of her works. The present study is taken from the translated version of the poems IduNingthou, 2005, there are 54 poems 
and 12 poems are taken up for study. The researchers have randomly chosen few poems to study there presentation of gender, class and society of Manipur from the poets "perspective.

\section{THE STUDY:}

In the poem "Songs of Singarei" is a 14 lines poems about a flower called singarei, its scientific name is, "Nyctanthes arbor-tristis, the night-flowering jasmine or Parijat or hengra bubar or Shiuli is a species of Nyctanthes native to South Asia and Southeast Asia".(Wikipedia). The flower blooms only once at night and next morning it's all scattered all over the ground spreading a saccharine smell all over the place. It was further explained in the Wikipedia page that the tree is also known as "tree of sorrow" or "sad tree" and it is said that in Tripura culture it is known as the garland of dead. The poet rejoices the status of the flower she says that it is not dead; the flower does not tell the story of sad and dead but it's more of celebrating of being alive. For the flower just performed the role assigned by the creator. It was specifically design that its duty was of spreading sweetness for a day that was given and eagerly waits for the next birth again. It's more about the expression of life rather than dead for the next birth waits for them. It echoes that it's not the number of days you stay here on this earth that matters but what you do here on this planet earth. The concluding lines of the poems say:

Tells the story of withered Singarei

Do yourself fondly think it the last

No, no, it's just the beginning of life

Of each and every birth. (11-14)

"My Small Baby" is a poem of only 12 lines. One cans feel the pride and joy of being a mother. The poet celebrates the role of motherhood and says that:

When you laugh heartily

The whole universe laughs

When you gambol

The sky, space, top-bottom

All are in waves

When you utter "mum-mum"

Your little immature language

The sweet-sounded echo

Makes noises in all directions.

Small baby

My small baby

I love you (1-12)

The poet, a mother herself expresses the joy of motherhood and her happiness in hearing the voices of her young innocent child. The poet is also excited like a child and embraces the innocent and newness of life. She like the child challenges to look ahead in future and create more beautiful poems and be more creative. She looks up to her child for their inquisitiveness and eagerness to explore the unexplored.

In the poem, "Honour", the poet expresses her anger and agitation against exploitation of women and discrimination of the rich and poor. She took the image of Phoolan Devi the real person and the cinematic Phoolan Devi played by Seema Biswas and says that:

Animals in the jungle of the world

Snatching the end of Phoolan Devi's cloth

Forcing her to fetch water from the well 
Phoolan Devi loses her honour

Seema Biswas loses her honour

Indian women lose their honour

All women lose their honour

No. No

Honour is lost

For all Indian men

Honour is lost

For all men of the world

Honour is lost

For you Creator also. (1-14)

It is a 14 lines poems, the poet emphasized that the disgrace of Phoolan Devi and Seema Biswas, isthe disgrace of all women in the Universe. The first paragraphs talks about the disgrace of women, how the animals in the jungle search for their prey, the so called mentally sick men hunt women to exploit and tear the body of women bare apart. The poem is more relevant in today's society whererape and sexual assault has become a new norm and normal by many. There is no newspaper or any plat form where the news about rape is not reported. The second paragraph of the poem is important, she says the disgrace is not the women alone but it's the men of the society their honour is lost and thepoet even blames the Creator, because HE fails to protects his own creation because he is a mutespectators to all the atrocities that is happening to the women especially. The incident of Phoolan Devi resonate an incident that happened in Manipur that shook the whole state. The killing incident of Thangjam Manorama a 32 years old woman by the Indian Paramilitary 17th Assam Rifles on 11th July2004. She was brutally raped and her body was mutilated and abandoned far away from her house. Is Manorama to be disgrace or the whole men who was involved in such a heinous act? The honour of the whole women of Manipur was at stake. Who is going to safeguard the women?

In the poem "The Day", the poet tries to find a fair and just society for all. She is not happy with the current situation of Manipuri society, where everyone is blindly following things without any moral conscience and running after power and status. She says:

Darkness hiding the whole universe

No division of darkness and light

No creation of the cosmos

Hiding all the energies

Darkness of the dark womb.

My eyes met one day

With those of a blind men. (14-20)

She compares the universe with darkness, for there is no just and fair world. Everyone is running a race to outsmart each other and overtake each other in terms of money and corruption and now with being viral over internet by doing crazy things. Where will all these leads to? So the poet compares the modern world with a blind man. The symbolic 'dark womb' is profoundly used there is peace in the mother's womb without tension or any problems, life generates in this dark womb, the poet look ahead for a better society with equal opportunity to all.

In the poem, "Give Me My today", the poet echoes the same as those of "The Day". The poet longs for a better Manipur. She wants to change the society for a better place to live in by all. She wants to bridge the gap of the poor and the rich and the discrimination of man and woman and she longs for a society where the girls and women are free to express their voices and build a constructive society. She says: 
February wind blows strongly

Monsoon rain rains heavily

In the summer sun's extreme heat

Wearily withstand the scarlet letters

Shouting without voice

Give me my today

I'll give you your tomorrow. (11-17)

The poet requested to give her today, without being bias or discrimination so that she can give a better tomorrow. Many a times girls are made to do compromises in terms of study or for the sake of the family so that the male child gets all the benefits. That's the reason the poet humbly request nature give women full opportunity to explore all the potential that god has bestowed upon them. If their today is not given to them, how can there be tomorrow for the women.

In the poem entitled "Bandh", the poet talks about few people in the name of Bandh tries to creates violence and bring about destruction. The poet says:

Pick up at the gate of these houses

Pick up the boulders and brick-bats

Strike with whatever you get

Throw, strike, throw

Isn't he dead as yet

If you kill, kill him to death.

Breaking, destroying, killing,

This is the only way for us (23-29)

Manipur in the late 80s and 90s witness frequent number of Bandh and strikes due to so many sociopolitical unrest and atrocities by the paramilitary to name a few. The tone in the lines is of hatred and malice, trying to harm or even killed someone in the name of Bandh. The frequent unrest has disturbed the normal lives of Manipur and the violence by the insurgencies as well as the paramilitary personal has left a deep impact in the psyche of the people. A sense of frustration is reveal and the poet knew well that violence would only leads to destruction.

The poem, "In the Depth of Clear water" is a 6 lines poem where the poet tries to catch hold of a beautiful society a nice place for all, but the moment she tries to jump and get hold of that, everything is just went in vain. To dear of a better world is like dreaming of something at is impossible. The poet says:

In life's depth of clear water

Brightly shining jewels

How anxious when seen from afar

When jumped down and collected curiously

They were nothing but

Thirst and pang. (1-6)

"Modern Woman" is also another short poem of 9 lines. Here the poet's compared modern women as like that of Mount Vesuvius, a volcanic mountain in Southwestern Italy which last erupted in 1944, which lead to the destruction of the ancient cities of Pampeii and Herculameum. The poet says:

Now 


\author{
Nothing is left to hide \\ I meeting this pang \\ Which has been hiding for many ages \\ Who knows to happen like this \\ Look now nothing is left \\ Except this fearful; ugly figure, remnant of pang \\ But I'm standing unashamed of anybody \\ I'm Visusvius, the Visusvius. (1-9)
}

The poet says that modern women know what she wants in life and she is unashamed to claim it too. If anybody tries to play with her, she can be like the Mount Vesuvius, and can destroyed everything. She haven't got her due for ages and keeping quite but now she will not stay quite anymore, she can speak for herself and assert her rights too. The case of domestic violence is not new in Manipur, but there are only few reports by the women, fearing of reporting due to the social stigma and thinking that the beating of wife is a common practice and justifiable in under some circumstances. The poet feels that it has to stop and the long denial of freedom of speech should be snatched back from the society for like lava it will ruin everything one day, when the women finally awake from her sleep. The poem also revealed the amount of frustration, torture, deprivation, and discrimination are bottle up for generations, which might burst out anytime.

"Night" is a short poem of 5 lines. Here one could feel the restlessness of the poet. She is tirelessly waiting for the icy cold winter to get over, so that we all could start a new life. Manipur was under the tremendous pressure from the insurgencies movement, kidnap, extortions, loot, blockade, fake encounters, AFSPA (Armed Forces Special Powers Act ,1958). The dark phase of Manipur is not yet over; it's been like one nightmare after another. She longs for a better Manipur where everyone can live in harmony. She says:
Though aware of nightmare
I can't but sleep
Waking from that nightmare
To be under nightmare from that waking
$\mathrm{O}$ ! how long is the night of Wakching (January)! (1-5)

In the poem, "You the Weak", a sense of anger and frustration can be felt by the readers. Here she is angry with women who are voiceless and cannot assert their identity.

For you the weak silently

Silently, silently, follow

On these ways trodden repeatedly

By many cowards like you

Bending down your neck

Looking down your two eyes

Go, go continuously go. (1-7)

The poet tries her best to motivate other women to join in the revolution to bring about changes, rather than being a mere spectator to discrimination. She is worried that if women just silently follow everything than there won't be any scope for changes, so she encourages not to blindly believes, for all women must join together to bring about changes and rectify the wrong done against women. 
"Darkness", is a short poem of 13 lines. The poet wants to wake-up the fellow citizens against the dark society of Manipur, where the people are indulging in corruption and mob lynching, and killing, wasting time doing nothing productive. The poems resonate with "Nightmare". The dark phase of Manipur is not yet over. It's like layers and layers of atrocities and disadvantages. The burning issues of unemployment youth are not channelizing their energy in positive outlook, the issues of drugs that toil the common people, gun culture that is slowly affecting the society and internal conflict between communities. The poet tries to bring sense to our youth to fight against corruption, mob lynching, discriminations and injustice. The poet sees no light but only darkness. The poet says:

Layers and layers of darkness

Opening and opening.

Look today in the dark

Darkness reigns (1-4)

In the poem entitled, "Phoolan Devi", here the poet expresses the plight of a woman. The poet says:

Mother earth's daughter Janakanandini

Whom Ramachandra himself couldn't protect

Say Phoolan who'll protect one like you?

Inside decent word and beautiful dress

Concealed knife glittering in the dark

Now the knife is in your hand

Or in theirs

Isn't it only what matters! (12-20)

This is the second poem in the collection where the poet has used Phoolan Devi as a symbolic representation of physical assault and how men tried their best to disgrace her. This particular poem revealed that when 'daughter Janakanandini' was not able to protect by her own husband 'Ramachandra', who is going to safeguard us, that is the big dilemma. The world has become a dirty and ugly place for the survival of women. Violence against women is becoming a common norm. How are we all going to combat this war? The poet tries to invoke a sense of duty to all the people of the society to contribute a sense of moral obligation to make this world a better to live in.

\section{CONCLUSION}

The collection of the poetry is a mixture of nature, feminist views, society, culture, class and tradition of Manipur, an amalgamation of the poet's view towards life and her experiences. The collection of this poetry ranges various themes from personal to universal. The poems are highly charged with intense emotion especially the Phoolan Devi where she tries to sketch a picture so true to the status of women in general, as well as in Manipur. Everybody is interest in talking about the disgrace of women but in reality it's not the disgrace of women alone but of the whole society who fail to protect their own women. Rape, physical assault was not so common in Manipur society at one time but it has became a normal news, the poet's feel sorry to see the degraded state of women where it has become a mere commodities like some show piece, a puppet without voice. She also urges the women to stand up and to raise their voices against the injustice done towards women in the name of social norm and tradition. The contribution of women is at par with the male counterparts in Manipur society. The poet also talked about the class division where people with corrupted mind are spoiling the society and she could see only darkness and nothing else. In few of the poems one could also witness that the poet longs for a new beginning, where she compared it with the seasonal changes of nature. The poet knew that silence is not the answer. 


\section{REFERENCES}

[1] Sigh, Ch. Manihar. A History of Manipuri Literature. Kolkata: Sahitya Akademi, 2013.

[2] Devi, S. Shantibala \& W.Kumari Chanu. Woman Activism In Contemporary Literature. Manipur: Writers' Club Manipur, 2015.

[3] "Promise of Creativity" by E. Nilakanta Singh. https://www.jstor.org/stable/23338827

[4] https://en.wikipedia.org/wiki/Nyctanthes_arbor-tristis

[5] https://en.wikipedia.org/wiki/Thangjam_Manorama

\section{AUTHOR'S BIOGRAPHY}

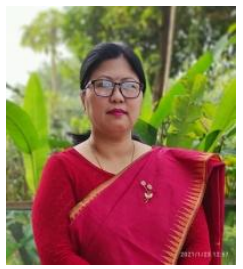

Dr. Anuradha Nongmaithem, is currently working as an Assistant Professor of English at the National Institute of Technology Agartala. She did her Masters, M.Phil, and Ph.D. at the University of Madras, Tamil Nadu. She graduated from D.M. college of Arts, Manipur. She is a keen lover of Manipuri literature, culture, dance, and customs. She is sensitive towards the downtrodden and who believes that every individual is equal. She has written more the 38 articles both in national and international journals, contributed more than 7 chapters in several edited books, and published poems in several anthology and has presented paper in national and international seminars and conferences. She has published two books. She is passionate about her teaching profession and loves working with young minds. She is currently working on compiling her unpublished poetry collections for publication. She is from Manipur where she resides with her husband and son she can be contacted at dranuradhanungmaithem@gmail.com / anunong08@rediffmail.com

Citation: Dr. Anuradha Nongmaithem. "A Study of selected poems from Sahitya Akademi Award-Winning Poetry Collection Idu Ningthou by Memchoubi" International Journal on Studies in English Language and Literature (IJSELL), vol 9, no. 5, 2021, pp. 15-21. doi: https://doi.org/10.20431/2347-3134.0905001.

Copyright: () 2021 Authors. This is an open-access article distributed under the terms of the Creative Commons Attribution License, which permits unrestricted use, distribution, and reproduction in any medium, provided the original author and source are credited. 